\title{
Change, Crisis, Perspective, and Identity in Two Novels by Rózsa Ignácz
}

\author{
Erzsébet DANI \\ University of Debrecen (Debrecen, Hungary) \\ Department of Library and Information Science \\ dani.erzsebet@arts.unideb.hu
}

\begin{abstract}
For Hungarians who remained stuck beyond the borders after WWI, finding themselves in a foreign country from one day to the next, the historical trauma of the Trianon Treaty occasioned intercultural tribulations never experienced before. What the resulting Transylvanian literature discussed here is concerned with, however, is not what Jeffrey C. Alexander's cultural trauma theory calls "the trauma process", "the spiral of signification" (Alexander 2004, 11). Rather, it is concerned with "the indelible marks" "the horrendous event" left "upon group consciousness [...] changing their future identity in fundamental and irrevocable ways" (Alexander 2004, 1). This literature displays a rich array of the management strategies of minority identity. Earlier I devoted a book to the identity types that ensued from those strategies (Dani 2016a). The present work is based on that monograph and moves on. This time I wish to focus on the key figures of two Rózsa Ignácz novels (Anyanyelve magyar and Született Moldovában) to demonstrate the complex identity patterns that an erosion of minority native language and culture, so destructive to identity, yields. The road that the Hungarian minority travels leads through a succession of active and reactive changes, crises, and modifications of perspective in the maze of minority versus hegemonic intercultural relations. ${ }^{1}$
\end{abstract}

Keywords: crisis, identity, native language, Rózsa Ignácz, Hungarian minority

\section{"It Has to be Written When You Feel the Inner Compulsion To."}

In my monograph study Identitásgyarmatosítás Erdélyben: identitásdrámák és interkulturális stratégiák a Trianon utáni székelymagyar irodalomban ("Identity Colonization in Transylvania: Identity Drama and Intercultural Strategy in Post-

1 The choice of the literary works to be discussed is also meant to be a tribute to writer Rózsa Ignácz so unfairly silenced by the communists and to her son, Ádám Makkai, poet, linguist, literary translator, and winner of the Kossuth Prize twice, on the first anniversary of his death. 
Trianon Székely-Hungarian Literature”) (2016a), Székely-Hungarian identity types were examined that cannot be described by using traditional analytical methods. My identity typology thus evoked the John Milton Yinger and the Beth Bowman Hess models of assimilation theories and the G. J. Ashworth-Brian Graham-J. E. Tunbridge theory of plural society. As for identity theory, I relied on Thomas Hylland Eriksen, William Bloom, J. P. Plamenatz, Anthony D. Smith, and György Csepeli. Jan Assmann provided the notion of cultural memory and its related concepts. Some categories of Homi Bhabha's colonial/postcolonial theory were also essential for those interpretations and reinterpretations. Karl Erik Rosengren's theory of communication as well as Everett M. Rogers and Thomas M. Steinfatt's theory of intercultural communication also contributed to the theoretical toolbox. ${ }^{2}$ The interpretive framework for handling the special situation of diaspora existence was furnished by the László Vetési ethnogram. ${ }^{3}$ The identity types that I set up can be grouped according to various perspectives; the monograph offers more than thirty choices for the reader of the discussed literary works, against which to test their own minority identity strategies. From the various manifestations of the natural human being of nature, i.e. uncolonizable identity, through the examples of self-destructive uncolonizability and identity-relinquishing conformity to the predicament of rootless I-identity, a good number of identity types can be established, which lead to a better understanding of minority existence on the one hand and endow us with a clearer insight of the often self-contradictory interpretations of today's European identity on the other hand.

The present study takes some of my earlier findings as its starting point and develops them further. Using the examples of two Ignácz novels (Rózsa Ignácz, 1909-1979), I hope to show how changes necessitated by historical and political pressure, causing the minority's changed relation to its native language and native culture, lead to language- and culture-related (and various other) crises; and what the perspectives that the individual, the group, minority society, or national minority can contemplate are.

"With the homelessness of the one who has two motherlands, I am being tossed back and forth between Transylvania and Hungary", we can read in a Rózsa Ignácz letter (Levelek Erdélyból - "Letters from Transylvania”; 1998, 5). ${ }^{4}$ The whole life and work of the writer - who was born in Székelyland, socialized in Transylvania, and then repatriated in Trianon-truncated Hungary (with Transylvania no longer part of it but belonging to Romania) - was hounded by the interlocking duality of "itthon" and "otthon"

2 (Yinger 1994, Hess 1988, Ashworth-Graham-Tunbridge 2007, Eriksen 2008, Bloom 1990, Smith 1991, Csepeli 1992, Assmann 2004, Bhabha 1998, Rosengren 2000, Rogers-Steinfatt 1999, Vetési 2001). For detailed justifications of introducing these theories, cf. the monograph itself.

3 For detailed justifications of introducing these theories, cf. the monograph itself.

4 The quotations from Ignácz Rózsa's novels are the author's translations.

5 Hungarian for "here at home" versus "at home there". 
of native land and home country and by her bond to her native language. Her life was imbued with her insistence on her roots to the extent that she succeeded in "passing" this strong emotional and intellectual relationship with Transylvania on to her (now late) son, Budapest-born poet, linguist, translator, and American professor Ádám Makkai. The professor professed, together with Széchenyi, that a human being lives in his or her language. His life took him to many places in the world, but "home" always meant one place only. He covered extreme distances between Transylvanian Kovászna and Hawaii, but what really mattered was the inner journey, in the course of which the broad scholarly "curiosity" of the linguist always returned to his mother tongue. Besides, Professor Makkai often revisited Transylvania, where he established close relationships with young Transylvanian-Hungarian writers; finally, he moved back to Hungary in 2015, after sixty years of emigration.

These are important items of information in our context - change, crisis, and perspective - since whenever Ignácz changed from home country to native land or back, change was always followed by crisis. The feeling of the homelessness of those who have two homelands often descended on her whenever she made a journey from home to home (from Hungary to Transylvania or back) - a change when the sense of homelessness intensified. "I am at home here in Pest; my family, my work, my subsistence are all here. Still, I go home every summer with the frenzied haste of someone drowning, for whom it is a matter of life or death to catch a quick breath of that singular air. The way I always set out: this is going to be my last, leave-taking trip" (Ignácz 1998, 5). Then, after a lengthier stay in Transylvania, the crisis grips her: "And I return determined that next year I will move home forever” (Ignácz 1998, 5). It is a sensation which could (also) be called the consciousness of the dual homelands.

Her dual-homeland consciousness amounted to more than what permeated the mind of the individual subject: it did not exactly enhance her reputation as a writer either. In order to be fully regarded as a Transylvanian author, she should have stayed in Kolozsvár (Ro: Cluj), and her works should have been published by Erdélyi Szépmíves Céh. In order to be regarded a Hungarian writer, she should have been associated more fully with Budapest (Neményi 2009, 6). Duality manifests itself in her "twin careers" too: she started out as an actress but then turned to writing. Some writers looked at her as someone who was "more of an actress"; for the theatre world, she was "more of a writer" (Neményi 2009, 5).

Her novels are filled with stringent social criticism, with the pain over the loss of Transylvania although "she did not cry and wail, did not weep for the return of everything, but gave us a realistic rendering of how the Hungarians lived under Romanian rule in Kolozsvár" (Makkai 2004). Multilingual, belletrist, and literary translator Ignácz's firm adherence to her mother tongue is partly atavistic. But it is deliberate too: "I know only one heritage that I am devoted to: my native language. I 
could talk about success, a successful life, I could say thanks for the free gift of talent only if I could rightly say that I was not only living by my mother tongue, however little, but I also did something for it” (Asszonysorsok és nôszerepek az irodalomban. Ignácz Rózsa). It is no accident, then, that several of her novels and other pieces of writing are permeated with the role native language plays in identity formation and preservation. Her characters exemplify how the life of a community forced into minority is shaped by the common bond of the mother tongue and how national and cultural identity are being destroyed by the erosion of the native language.

The title of her first novel - Anyanyelve magyar (Native Language: Hungarian) (1937) - is already indicative of the strong Ignácz-mother-tongue relation just outlined. The protagonist, Ilona Kovács, is a portrait of the artist. The mentality Ilona represents and the opinions she offers are loaded with a view of the world based on Ignácz's personal experiences, combined to become the novel's ideological discourse. This work lays before us the events of the Kolozsvár high-school years: the way the Hungarian student, while exploring her possibilities in the postTrianon Romanian world, is confronted with the aggressive assimilative attempts of the majority culture. This is not done by this Hungarian author as an accusation of Romanian power pressure, nor with intensified literary techniques, nor is it overdramatized. The same is true for Született Moldovában (Born in Moldavia) (1940), a novel that presents the broadest spectrum of identity management by members of the Székely-Hungarian minority community. At the time of writing that novel, Ignácz could not yet have met modern theories of assimilation, colonialism, post-colonialism, and diaspora. Nevertheless, she depicts adroitly the process that could be adequately described with those would-be theories: the way the erosion and stigmatization of the mother tongue, language exchange, bilingualism, and linguistic assimilation (may) lead to the total abandonment of cultural and national identity. What the novel shows us is authentic. Ignácz did not simply rely on her creative fantasy, or, at best, on information acquired from secondary sources to be able to delineate the tragic identity drama of the Csángós. ${ }^{6}$ She researched the subject on the spot. The results of that and her personal experiences went into her description of the characteristic features of Moldavian Csángó life, the nativelanguage aspect included, assimilation, cultural identity, religious life, diaspora life, and the painful present of all these.

When the textual subjects of the two Ignácz novels are examined in the context of the mother tongue/identity formation relation, the two protagonists claim our attention: Ilona Kovács of Anyanyelve magyar and Dávid Gergely of Született Moldovában. According to the identity typology established in my earlier work quoted above, Ilona's identity pattern is multiple-stage, forced minority-identity management, while Dávid's one is rootless I-identity ${ }^{7}$ tribulations. Through

$6 \quad$ Hungarian-speaking natives of Moldavia.

7 According to Jan Assmann, identity has two forms: I-identity and we-identity. For the sake of a 
the character of Ilona, an omniscient narrator relates the events of the author's Kolozsvár student years in a diegetic fashion. So, the implied author creates the textual universe of Anyanyelve magyar through a non-dramatized, extradiegetic narrator, to use Gérard Genette's well-known terms (Genette 1980, 228; 1988, 132134). The implied author of the other novel, Született Moldovában, also speaks through an extradiegetic narrator, who is not dramatized either. In the background lies what Ignácz accumulated as a result of on-the-spot research of several months in Moldavia, as has already been mentioned. The narrators of both novels would certainly agree with the view expressed by Sándor Balázs concerning majority culture strategies deployed against the minority: "[i]t is through withering culture that national identity must be made unfunctionable" (Balázs 1995, 97). Both novels are a penetrating study of exactly that hegemonic effort.

\section{Identity}

The notion of identity has no single definition; we have no theoretical model based on general scholarly consensus since we have countless "identities", conceived on diverse conceptual bases: national, cultural, ethnic, diaspora, individual, collective, double, majority, minority identity, and more. This paper, with its focus on the role language plays in identity formation, will embrace János Péntek's concept of identity as most relevant. It is a theory that states: identity is nothing else than the answer to the question "who am I?", "what am I?”. Péntek asserts that "native language” is not simply a sociolinguistic category as it is also charged with emotional and symbolic content attached to it by a narrator or by her/his community. Furthermore, if a speaker and a background community identify themselves in the same language, thus distinguishing themselves from everyone else, "the symbolic value of the native language becomes more intensive” (Péntek 2010, 161-162).

We can also have recourse to Ferenc Pataki:

Identity becomes a problem - that is, self-definition causes tension and difficulties - where and when, as a result of increasing social differentiation and the emergence of the individuated social self, identity categories become gradually detached from their natural, inherited, and fixed basis. They will be more numerous as a result and lose their rigid adhesion to the individual. The notional richness of articulating and handling reality with the other human being and ourselves in it - will increase.

better understanding of how collective sociocultural identity works, the "I" must be divided into "individual" and "personal" identity. Individual identity "builds itself up in the consciousness of the individual"; personal identity falls to the lot of the individual from society, it follows from his or her "special place in the social network" (Assmann 2011, 111-113). 
What Pataki adds - "On the other hand, the individual is granted more and more ample free scope to realize choices, decisions, conscious, and chosen identity manoeuvres" (Pataki 1986, 14) - is pertinent as an abstracted distillation of identity's essence. In post-Trianon Transylvania, however, these are the very operations that history and politics deny the Székely-Hungarians.

\section{Patterns of Minority Identity, Viewed in the Triple Framework of Change-Crisis-Perspective}

What follows below is an attempt to outline, in the triple framework, the formationprocess of key characters Ilona Kovács's and Dávid Gergely's identity types (i.e. multiple-stage identity management [Dani 2016a, 123] and the development of rootless I-identity [Dani 2016a, 183]) with the help of relevant segments of the two narratives.

Therefore, with close attention to the details of the two storylines, I tried to keep track of the various changes, also the crises these changes may have generated as well as of the impact those crises exert on the two narrative agents (Ilona and Dávid, whose fates determine the main directions of identity discourse in the novels). This will be done from the point of view of their perspectives (how they can get on in life and/versus to what extent they are able to retain their language and culture). An overview of my findings follows now, with detailed elaboration later below.

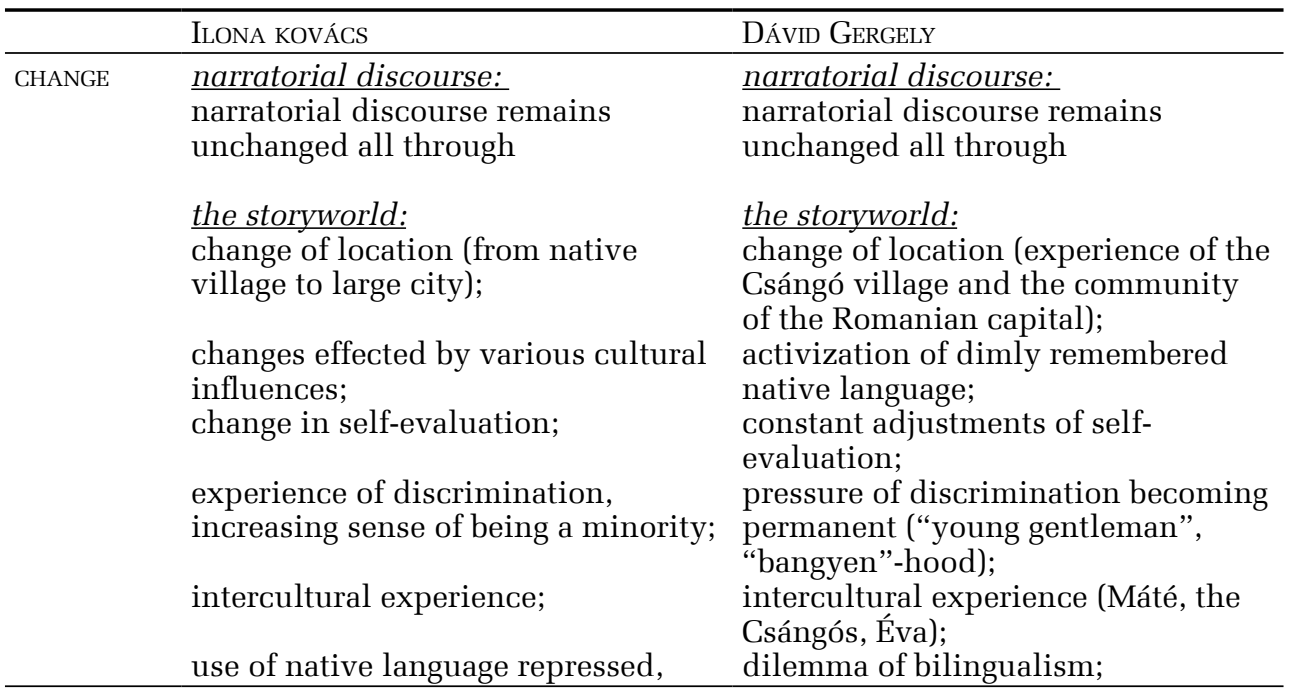




\begin{tabular}{ll}
\hline ILONA KOVÁCS & DÁvID GERGELY \\
\hline pressure of majority culture steps & $\begin{array}{l}\text { native language and Hungarian } \\
\text { culture periodically erupt from } \\
\text { under the surface (pulsating }\end{array}$ \\
$\begin{array}{ll}\text { change in the (individual and } & \text { awakening to native culture); } \\
\text { change in the (individual and }\end{array}$ \\
personal) segments of I-identity - no & personal) segments of I-identity - \\
doubling of identity; & doubling of identity; \\
changes in we-identity; & changes in we-identity; \\
interrelationship of career & interrelationship of career \\
expectation and change & expectation and change \\
existential crisis; & no existential crisis; \\
identity crisis; & identity crisis; \\
the crisis of I-identity (individual & the crisis of I-identity (individual \\
and personal); there is no we- & and personal) and we-identity; \\
identity crisis; & \\
the where-am-I-at-home crisis & the where-am-I-at-home crisis \\
\hline chISIS & change of identity; \\
name-change; & no change of name; \\
language changed; & bilingualism (is it possible?); \\
assimilation; & rootlessness versus assimilation; \\
career guaranteed; & career guaranteed; \\
OR: return to the pre-change & OR: assimilation (aborted \\
world (she finds her way back to & assimilation attempt: Dávid dies) \\
Hungarian identity) & \\
\hline PERSPECTIVE & \\
\hline
\end{tabular}

\section{Changes}

My uniform theoretical guidance in discussing the triple problematic of change, crisis, and perspective will be the theoretical background expounded in the first („Changes”) subchapter.

Relying especially on Yuri Lotman (among others), Peter Hühn defines what can be regarded to be an "event" in a narratological sense as a "decisive turn" in the life of the character(s) $(2016,37-38)$. "Decisive turns" in our context are turning points or at least crucial experience impacting minority predicament or eliciting major response from minority identity; for instance, effecting a change in a determinant of minority identity (like use of the native language); but resistance to the pressure to change can itself become a determinant of minority strategy.

The above table indicates ten changes in the life of the two key characters, where the use, loss, or abandonment of the native language is a catalyst in the background. (Read more about it below.) There is a common factor in the two cases, though. It is the absence of change in the narratorial discourse as opposed to the varied picture that the changes in the storyworld characters' thinking, attitudes, and actions present. While there is no change in narratorial presentation, we cannot sense overdramatization either, in the way the narrator handles the motivation, consciousness of storyworld narrative agents; no hidden 
critique, no suggested narratorial agreement or disagreement can be detected. In other words, Ignácz's are not judgemental characters.

In the Ilona Kovács story, change of location is one of the important changes. The switch is from the community of a pure Székely-Hungarian village to the multilingual and multicultural environment of a Transylvanian large town. Nature symbolism is indicative of what it meant to arrive from the spring into winter: "fog descended from the alps of Gyula [...] it climbed up along the gutters to the eaves. It entwined the pillars of the church. Mildly, soft and snow-white. Kolozsvár was engulfed by the fog... December nineteen twenty-seven...” (Ignácz 1990, 28). The young Székely village girl is confronted at every step with what remains of the old, bygone Hungarian world. The aged representatives of the Hungarian aristocracy construe a peculiar interpretation of the "the new world's" gaining ground: the identity challenges of the post-Trianon present make them retreat into the cultural memory of the past. In cognitive narratological terms, this is what determines their cognitive architecture and inner representation. Theirs is a vanished world: "I can still see the house half-sunk in the ground. Its mouldy walls wobbly under the huge roof. It is squatting scared at the corner of Egyetem street, across the cemetery. In Kolozsvár, under Majálistető”8 (3).

It is in this environment that Ilona lives as a Hungarian, with every cultural influence (Romanian, Jewish, and Saxon schoolgirls, together with the more and more arrogantly dominant Romanian culture) making her sense of being a minority citizen stronger. They exert a negative influence on the individual and personal segments of her I-identity. "Tough little Hungarian is how Rebrescu mocks me at school". And then, trying to imagine what it would be like to live in Budapest: "I wonder how they would tolerate me, or they too would ridicule me in the student's canteen there with my Mongolian cheekbone?" (222). What is more, the supremacy of the Romanian schoolgirls, her roommates, humiliates the Hungarian in her (even if the remark is not meant specifically for her but for the Hungarian servant): “you stupid yokel! Au, tu unguruaica tu!” (12).

No wonder that her self-evaluation is changing, too. In the succession of events, she tends to see her being a Hungarian in an increasingly negative light as a result of continual discrimination (they deride her as “Tartar-headed Kovács”). Her relation to what for her is a foreign language and culture is apparent, feigned, in fact - in Bhabha's terms -, cultural mimicry. Genuine multiple group identification $^{9}$ is out of the question here, when we are dealing with a hegemonic sociocultural majority pressure, which demands your cultural identity in exchange for social opportunity. Ilona undergoes some transformation in the course of all of this, though. As a matter of fact, she can barely notice how close

8 "Majálistetô" means "May-picnic hill” (Hungarian).

9 On multiple group membership, see sociologists Vernon L. Allen, David A. Wilder, and Michael Atkinson (1983, 92). 
her minority cultural identity comes to being colonized by hegemonic majority culture, too. It is because she is a talented student, cut out for foreign languages, too. When asked by the inspector if she wished to do her geography examination (at the high-school-leaving examination series) in Hungarian or Romanian, she chooses the latter. But with her it is a momentary manifestation of the situational identity ${ }^{10}$ of an enthusiastic student, and not sociocultural positioning at all.

A direct consequence (and a catalyst) of these changes is that the native language is pressed back more and more. Owing to her Romanian-language schoolwork, Ilona's Hungarian is no longer faultless in spite of the fact that she was socialized in a Hungarian environment. Her language competence begins to dwindle, slowly but steadily: "Geography, history, constitucia. Contitucia. What is it in Hungarian? Good grief! She no longer speaks Hungarian" (21). What is more, the assimilative weight of the majority culture whose aim is also to wither minority language is educating the girl to think in Romanian: "Think in Romanian - Miss Suciu, the history teacher said -, and you will no longer use so many incorrect expressions" (21).

This is what makes minority feeling permanent and bad social stereotypes stronger: it reinforces the social conditioning which maintains that the majority culture is more valuable, therefore superior; so convinced, majority culture will, in turn, really look down upon minority culture as less valuable, inferior. It backgrounds native language (too), and eventually leads to the deformation of both segments of Ilona's I-identity. Her Hungarian friends need to step in, collective we-identity must interfere to prevent the total loss of identity that Ilona has been managing in a multi-stage fashion. ${ }^{11}$

In the background of the process, beset with changes, we find Ilona's career plans for the future. For a Székely-Hungarian to be able to make her own way in life, a diploma is needed (it is her aspiration to be a physician), but Romanian language is a degree requirement. The greater the extent to which she becomes Romanian, the better chances she has of succeeding in society. A direct consequence of this is, however, that Ilona no longer identifies herself in her native language, and she is thus gradually drifting away from the group which provides her we-identity. The disintegration of native language skills is only the beginning. Another indicator of encroaching assimilation is name change. Ilona Kovács can or could become Dr Ilona Covaciu: "If ... you become doctor Covaciu, it will not hurt you at all" (252); "Rebrescu advises me to change my name to Covaciu when I enrol [i.e. at the university]. I wonder why she cares for me so much?” (253). The majority culture's assimilation strategy that pushes Ilona Kovács towards becoming Ilona Covaciu and capitalizes on her wish to be getting

10 On situational (or small) versus large (social) identities, see Alexandra Georgakopoulou 2006, 96-100.

11 On multi-stage minority identity crisis management, cf.: Dani 2016a, 123-129; 2016b, 23-25. 
on in the world is causing confusion in her information processing and inner representation - the first steps in the gradual but systematic dismantling of her minority identity.

Gergely Dávid (or should we say "David Ghergheli"?) is culturalized in a Romanian environment from the very start. He loses his Hungarian mother early; the father - who embodies the conformity of abandoned identity - becomes Adalbert Ghergheli and departs for Bucharest, leaving his son behind. The boy, who is left without a family, is being raised by a Romanian family in a small Moldavian village. He does not speak his native Hungarian; the music and the rhythm of his mother's words are not more than vague memories. While in Ilona's case the question is whether her steady sense of Hungarian identity can waver or even be shaken and destroyed, the Romanianized father's son's, Dávid's native identity is shaky and staggering from the outset.

Change of location will gain central significance in Dávid's identity tribulations when he visits the family of his schoolmate for a longer period of time in a Moldavian Csángó village. His sense of rootlessness begins to subdue when he meets the Csángó community for the first time: "Because sometimes you live years in just moments, and there are pictures that dig themselves into you forever. He saw it for the first time, and saw it like this ever after" (Ignácz 1997, 149). David is a man of double identities, in a sense. Both the individual and the personal segments of his I-identity are charged with Romanian identity; Hungarian language and culture are a barely glimmering, fading memory. His everyday direct contact with Romanian-majority environment and culture drives this individual closer to the cultural Other, to integration into the other culture. He has no own (Hungarian) cultural group (or we-) support; moreover, his cognitive functions, value system, and representations are extremely reduced. His emotional attachment to his own culture vanished in the past: his Hungarian identity is latent, consisting of threadbare elements of the native language.

Changing cultural circumstances have a twofold influence on him: right at the beginning of the novel, he meets Máté, the Székely on the run, and comes under his influence. He owes the activation of his native-language memories to Máté. Dávid remembers only the first line of the Hungarian evening prayer (even that with a Romanian accent), and is not even sure that the line is Hungarian: "I don't remember how it goes on. Tell me, is this Hungarian speech?" (12). He admires the Székely young man's dress, habits, reactions, and the Romanian he speaks with a Hungarian accent. His sense of rootlessness gets somewhat dissolved, while still being tossed about between the Hungarian and Romanian cultural sway. The Romanian high school community, Máté's unwavering Hungarian identity, the customs of the Csángó village (that Dávid often finds difficult to describe), the cultic use of (atavistically survived) snippets of Hungarian language - all mutually impacting one another - land Dávid in a serious identity crisis. 
His rootlessness gives him a sense of insecurity in the first place, but processing the world more and more makes his identity more and more unsteady: "And I have to decide at last, now, at the age of fifteen, before choosing a career and stepping out into life what I am after all? [...] Which is my people, Niculai?" (102-103), he is asking his Romanian friend in despair. He puts this feeling into words for the Hungarian monastic of the village, too: "What I am ashamed of is that, like Máté, I am neither outside nor inside [...] that I can be neither Romanian nor Hungarian. I am ashamed of what I am, and I am looking for... what, after all, Father. What am I? Something between the two, something that everybody in it is ashamed of. Something, which is a disgrace [...]" (174).

The question plagues him more and more. The Székely-Hungarian Máté could be his direction indicator, his point of orientation, a fixed point for Dávid. Máté could be "the ancestor" that Toni Morrison speaks about apropos of black American literature in her "rootedness" essay: "these ancestors are not just parents, they are sort of timeless people whose relationship to the characters are benevolent, instructive, and protective, and they provide a certain kind of wisdom". "The absence of an ancestor" is "frightening", "threatening" (Morrison 1990, 330). Máté is a proto-, primaeval Székely after all. He is there for Dávid. But the cultural confusion in Dávid's soul does not let Máté fulfil the role of "the ancient", to provide rootless Dávid with a sense of rootedness. (Ilona does have her "ancestor" too, Feri Borbáth, her friend, another uncompromising Székely.)

But besides Máté, the diaspora community of the Csángó village (they speak Romanian but pray in Hungarian at church) and later on the small Reformed Church congregation of the Hungarians in Bucharest (who all have their different methods to awaken the young man to the realization of the importance of his native culture and language) - could all serve as handholds for Dávid to hold onto. Their we-identity could be a firm support for his wavering I-identity in his rootless existence.

Another motivating reason for the confusion of self-assessment is ceaseless discrimination ("something, which is a disgrace"): "bangyen"-hood. ${ }^{12}$ They constantly make him feel that he is displaced, that he has no home country; whichever way he turns, Hungarian extraction means immense disadvantage in this intercultural space (he used to be scoffed at as "little gentleman" in the Romanian native village of his childhood). He ventures in the direction of bilingualism, but this makes his already unstable identity even more unsure. And the vortex of rootlessness pulls him down only deeper. On the one hand, he is open to Hungarian language and culture, to Hungarian Reformed religion (his renegade father had him baptized Greek Orthodox originally). On the other hand, numerous factors - the Romanian-Hungarian double impact systems, the false-consciousness strategy of the history teacher, not mentioning his father's 
example, who discarded his identity - keep pulling him back into an identity crisis whose source is, again, his rootlessness.

His experience of the Hungarian Reformed Church community of the Romanian capital city (the city of the "bangyens", in terms of the novel's world) is promising. But its identity benefit is ambivalent. True, the Hungarian housemaid, who does not speak Romanian, and Éva, the Protestant minister's daughter, both exert an influence on both segments of Dávid's I-identity, although first they treat him as someone with double identity: "I said this to Mr Ghergheli only... If I were to speak to Mr Gergely... I would be saying something quite different" (276). The Hungarian community ensures strong, unambiguous Hungarian we-identity for Dávid, no doubt, and his socially-based personal identity is strengthened by it. Learning Hungarian plays a definite role in this: "snappish, cracking, hard language is this Hungarian. When he spoke Romanian, the words were asleep in his mouth, so it seemed sometimes; the soft, guttural sounds were dropping out of his mouth with such self-evident laziness. [...] But Hungarian double 't' and double 'l' put his attention and vocal cords to the test all right [...]. I will change, I will start a new life!” (300). His returning cultural memory, his mother's vaguely remembered snatches of words bring him increasingly closer to his mother tongue: "My God! ... Indescribable, celestial happiness fills him since all of them, all of them are here with him, he hears, he knows that his mother is speaking to him, Máté encourages him, and Ersze whispers" (164). ${ }^{13}$

Still, Dávid's tragedy is inevitable. David Ghergheli's plans for the future (he would like to be a degree holder) and his childhood friend's cultural and political nationalism drive him in the direction of the Romanian fascist organization, the Iron Guard, something that eventually means Dávid's death. As Dávid Gergely, he was Hungarian-born; as David Ghergheli, he was socialized in a Romanian environment. His native language and minority identification could not recover enough to enable the Székely-Hungarian Dávid Gergely, a man of rootless I-identity from the start, to assert himself as a Székely-Hungarian in Bucharest's chaotic life.

\section{Crises}

The changes discussed above lead up to crises in both characters' lives. Ilona Kovács has to cope with a serious existential crisis provoked by changes arising from the need to leave her native village in order to pursue her studies (and in Romanian at that!) so as to be able to make her way in life. Gergely Dávid/David Ghergheli is not confronted with an existential crisis. He is already a secondgeneration "renegade", even if it is involuntary and not unambiguous - reasons why the identification issue can precipitate into tragic identity tribulations for him.

13 In the Csángó name usage Ersze means Elisabeth. 
The father, justifying his decision with his consideration for his son (but regarding his own plans to succeed in life in fact) becomes a conformist, who gives up his Hungarian identity. The background that looms behind it all is what Daniel R. Miller theorizes as "the tyranny of the immediate social context" (Miller 1983, 326). In our case, it is the tyranny of being forced into minority existence, in which social opportunities are curtailed unless you switch sociocultural identification, as the father did (and his son will, too, eventually). This is how Gergely Béla goes for the Romanian identity of Adalbert Ghergheli, switching group affiliation and discarding who he was before. What he means by saying that he undertakes the move of assimilation (also) out of regard for his son is that Adalbert Ghergheli does not want his son to be an alien in his own country; he does not want Dávid to live the life of a "bangyen". It is the father's deliberate intention that his son should grow up to be an unquestionable Romanian. In order to achieve this, he cuts his son off from his native language, from Hungarian culture and religion. True, he does secure him livelihood.

It seems that the existential crisis, which grips the father, costs him his native language and culture. What he is presented with is the imperative of language change and culture change, the command to achieve his goal in another sociocultural environment. His sociocultural positioning is motivated by something that can be grasped with multiple group membership theory. Gergely Béla lays emphasis on "the evaluative dimension" of the identification issue: on "how well am I doing?". With him, the "who am I?" matters less. ${ }^{14}$

The identity crisis that Ilona and Dávid toil over is intense, involving identity confusion, the erosion of the native language taking the lead role in the background with the alternating intensity of loss and retainment. The overall pattern in Ilona's case is retainment $\rightarrow$ loss $\rightarrow$ retainment; in Dávid's case: loss $\rightarrow$ retainment $\rightarrow$ loss. Numerous small incidental details - plot elements, considerations, dilemmas, possibilities, and impossibilities - are teeming inside both patterns.

The identity crises of both characters are closely related to the pulsating impacts of the we-identities that reach them with alternating intensity, frequency, and with mostly contradictory message load, from the minority and the majority cultures that surround them. The I-identities of the two character agents are being shaped or deformed in relation to the decreasing or increasing intensity of sameculture or hegemonic-culture impacts with signs that are positive or negative, depending on identity programmes and representations.

The chain of changes, crises, and perspectives leaves its strong and characteristic imprint on the final outcome in both cases. The where-is-home issue becomes clearly defined behind Ilona's resolute decision. Her home in the world can only be a place where her identity crisis disappears. So, she returns to

14 For the theoretical aspect, see Allen-Wilder-Atkinson 1983, 95. 
her motherland. Quite the contrary, Dávid's identity tribulations develop into a tragedy: he is denied the sense of home by his rootlessness.

\section{Perspectives and Conclusion}

Both Ilona and Dávid have two roads to travel. As for the high school student, the narrator leaves no doubt about the choices she has. Ilona either changes her national and cultural identity and steers her course towards total assimilation through changing her name and language, and then the road to success in the world is open for Ileana Covaciu, or deliberately steers clear of assimilation and returns to her Székely-Hungarian (national and cultural) minority community to go on seeking her place as a Hungarian minority in her own native community. The Kovács pattern is clear - the narrator makes her decision: Ilona goes home.

Dávid's identity-related vicissitudes are much more complex, and his perspectives are aligned with this: the opportunities to choose from are generated around him in several phases, under double pressure. He has no time - and the fast pace of events does not let him - to fortify his I-identity with the help of his latent cultural memory, with his openness to the barely remembered mother tongue. In other words, circumstances do not let his native-language culture and we-identity fortify his I-identity to the degree that would help him change his name and identity in the opposite direction - back from David Ghergeli to Gergely Dávid - and thereby assimilate into his own national community. The boy was torn out of his native minority community, and his assimilation into majority culture is so strong that he himself is incapable of altering the course of his own life. The only realistic perspective left for him is annihilation.

In Pataki's terms (quoted above), applied to Dávid's specific case, Dávid's identity became "detached" from its "natural, inherited, and fixed basis". Pataki also argues that "[t]he individual should always be able to say where he is 'at home' in the world after all" (Pataki 1986, 16). This is exactly what a minority individual, set on the course of loss of identity, can no longer say.

\section{Works Cited}

Alexander, Jeffrey C. 2004. "Toward a Theory of Cultural Trauma”. In Cultural Trauma and Collective Identity, ed. Jeffrey C. Alexander et al., 1-30. Berkeley: University of California Press.

Allen, Vernon L., Wilder, David A., and Atkinson, Michael L. 1983. "Multiple Group Membership and Social Identity”. In Studies in Social Identity, eds. Sarbin, Theodore. R. and Scheibe, Karl. E., 92-115. New York: Praeger. 
Ashworth, G. J., Brian Graham, J. E. Tunbridge. 2007. Pluralising Pasts: Heritage, Identity and Place in Multicultural Societies. London-Ann Arbor MI: Pluto Press.

Assmann, Jan. 2004. A kulturális emlékezet [Cultural Memory]. Budapest: Atlantisz.

2011. Cultural Memory and Early Civilization: Writing, Remembrance, and Political Imagination. Cambridge: Cambridge University Press.

"Asszonysorsok és nőszerepek az irodalomban. Ignácz Rózsa”. web. https:// mediaklikk.hu/video/asszonysorsok-es-noszerepek-az-irodalomban-2-2ignacz-rozsa/\# (Last accessed 13 March 2021).

Bhabha, Homi K. 1998. The Location of Culture. New York: Routledge.

Balázs, Sándor. 1995. Identitástudatunk zavarai [Disorders of Our Identity]. Bucharest: Kriterion.

Bloom, W. 1990. Personal Identity, National Identity and International Relations. Cambridge: Cambridge University Press.

Csepeli, György. 1992. Nemzet által homályosan [Nation by Obscurity] Budapest: Századvég.

Dani, Erzsébet. 2016a. Identitásgyarmatositás Erdélyben: Identitásdrámák és interkulturális stratégiák a Trianon utáni székelymagyar irodalomban [Identity Colonization in Transylvania: Identity Dramas and Intercultural Strategies in the Szekler-Hungarian Literature after Trianon]. Miercurea Ciuc: Pro Print. 2016b. "Székely-Hungarian National and Cultural Identity Strategies Beyond the Trianon Borders". Hungarian Cultural Studies: E-Journal of the American Hungarian Educators Association vol. 9, no 1: 11-27.

Eriksen, T. H. 2008. Etnicitás és nacionalizmus: antropológiai perspektívák [Ethnicity and Nationalism: Anthropological Perspectives]. Budapest-Pécs: Gondolat Kiadó - PTE Kommunikáció- és Médiatudományi Tanszék.

Genette, Gérard. 1980 [1972]. Narrative Discourse: An Essay in Method. Transl. Jane E. Lewin. Ithaca, NY: Cornell University Press.

1988 [1983]. Narrative Discourse Revisited. Transl. Jane E. Lewin. Ithaca, NY: Cornell University Press.

Georgakopoulou, Alexandra. 2006. "Small and Large Identities in Narrative (Inter) Action”. In Discourse and Identity, eds. Anna De Fina, Deborah Schiffrin, and Michael Bamberg, 83-102. Cambridge: Cambridge University Press.

Hess, B. B., Markson E. W., and Stein P. J. 1988. Sociology. New York: MacMillan. Hühn, Peter. 2016. "The Eventfulness of Non-Events”. In Narrative Sequence in Contemporary Narratology, eds. Baroni, Raphaël and Revaz, Françoise, 37-47. Columbus OH: Ohio State University Press.

Ignácz, Rózsa. 1990. Anyanyelve magyar [Native Language: Hungarian]. Budapest: Püski. 
1997. Született Moldovában [Born in Moldavia]. Budapest: Püski.

1998. Levelek Erdélyból [Letters from Transylvania]. Budapest: Püski.

Makkai, Ádám. 2004. "Ignácz Rózsa helye a magyar irodalomban”. Korunk (December 2004). http://makkai.org/ignacz/ignacz_rozsa_helye.php (Last accessed 12 April 2021).

Miller, Daniel. R. 1983. "Self, Symptom, and Social Control”. In Studies in Social Identity, eds. Sarbin, Theodore. R. and Scheibe, Karl. E., 319-338. New York: Praeger.

Morrison, Toni. 1990 [1984]. "Rootedness: The Ancestor as Foundation". In Literature in the Modern World: Critical Essays and Documents, ed. Walder, Dennis, 326-332. Oxford: Oxford University Press.

Neményi, László. 2009. Ignácz Rózsa (1909-1979) [Rózsa Ignácz (1909-1979)]. Miercurea Ciuc: Pro Print.

Pataki, Ferenc. 1986. Identitás, személyiség, társadalom: Az identitáselmélet vitatott kérdései [Identity, Personality, Society. Debated Questions of Subject Theory]. https://adtplus.arcanum.hu/hu/view/ErtekezesekEmlekezesek_064/? $p g=4$ Elayout $=s$ (Last accessed 8 April 2021).

Péntek, János. 2010. “Anyanyelv és identitástudat” [Mother Tongue and Identity]. Debreceni Szemle vol. 18, no. 3: 160-168.

Rogers, E. M. and Steinfatt, T. M. 1999. Intercultural Communication. Long Grove. Illinois: Waveland Press.

Rosengren, K. E. 2000. Communication: An Introduction. London: SAGE Publications.

Smith, A. D. 1991. National Identity. London: Penguin.

Yinger, John M. 1994. Ethnicity: Source of Strength? Source of Conflict. Albany: State University of New York Press.

Vetési László 2001. Juhaimnak maradéka: anyanyelv, egyház, peremvilág: sorskérdések a nyelvhatáron [Remnants of My Sheep: Mother Tongue, Church, Periphery: Fate Issues at the Language Boundary]. Cluj-Napoca: KOMP-PRESS - Korunk Baráti Társaság. 